\title{
Intelligence Community Reorganization: Declining the Invitation to Struggle
}

\author{
Russell J. Bruemmer $\dagger$
}

The recent confirmation hearings of Robert Gates to become Director of Central Intelligence (DCD) have focused debate over the proper role for future U.S. intelligence activities. Coming at a time when the existing world order of the last four decades is crumbling at a free-fall pace, the hearings have raised questions about whether an intelligence structure originally designed to confront very different world circumstances is still relevant. Though the Cold War may be over, the need for intelligence in shaping U.S. foreign policy will continue unabated. Despite a far more favorable climate for the United States and its allies, it is clear that international threats and issues remain significant. Shrinking U.S. military forces may make the contribution of intelligence to U.S. national security and foreign policy even more important. This Essay examines how the Intelligence Community's structure should be reconsidered in light of the changed international environment that the United States now confronts.

In 1947, Congress addressed shortcomings in the intelligence structure that contributed to the Pearl Harbor disaster. Under the statutory regime of the National Security Act of 1947, Congress created the Central Intelligence Agency (CIA) as the preeminent U.S. government agency to receive and interpret intelligence from all sources. ${ }^{1}$ The statute also codified the position of DCl. ${ }^{2}$ Administering the CIA is one of the DCI's key responsibilities, but the National Security Act designated the head of the CIA as the Director of

† Partner, Wilmer, Cutler \& Pickering, Washington, D.C.; J.D., University of Michigan Law School, 1977; B.A., Luther College (Iowa), 1974; General Counsel of the Central Intelligence Agency (CIA), 198890; Special Counsel to the Director of Central Intelligence (DCI) for Iran-Contra matters, 1987; Chief Counsel, Congressional Affairs for the Federal Bureau of Investigation (FBI), 1980-81; Special Assistant to the Director of the FBI, 1978-81.

In 1991, the author served as a member of the DCI advisory group described in this Essay that studied the structure of the Intelligence Community. While some of the information contained in this Essay was derived from that study, and this Essay was reviewed by the CIA to ensure that it does not contain classified information, the views expressed are solely those of the author.

1. National Security Act of 1947 , ch. $343, \S 2,63$ Stat. 579 (codified as amended at 50 U.S.C. $\S \S 401$ 405 (1988)).

2. In addition to creating the CIA and codifying the position of the DCI, the National Security Act of 1947 also created the position of Secretary of Defense and established the current structure of the three military departments. For a general description of the CIA's predecessors, the Office of Strategic Services, and the Central Intelligence Group, and of the events that resulted in the enactment of the National Security Act of 1947, see JoHn Ranelagh, THE AgENCY: THE RISE AND DECline of THE CIA 37-111 (1986). 
Central Intelligence and did not limit his duties to those involving the CIA. ${ }^{3}$ Instead, the DCI coordinates the intelligence activities of all of the various agencies and entities that comprise the Intelligence Community.

Today's changing geopolitical landscape challenges the capabilities of the agencies that comprise the Intelligence Community and the structure that binds them together. Both congressional intelligence committees-the Senate Select Committee on Intelligence and the House Permanent Select Committee on Intelligence-are reviewing the Intelligence Community's structure. In early 1991, then-DCI William Webster convened an advisory group of eight former senior officials from six Intelligence Community agencies to consider the issue. In addition, the Secretary of Defense last year approved a proposal that would significantly change the structure of the Intelligence Community agencies that are part of the Department of Defense (DoD).

Part I of this Essay describes the challenges that the Intelligence Community faces in the next decade. Part II describes the organization and function of the Intelligence Community and the role of congressional oversight in reviewing Intelligence Community activities. The prospect of significant changes in the Intelligence Community's mission calls for a reexamination of existing Intelligence Community structures, capabilities, and authorities.

Part III proposes procedures to effect restructuring. Most importantly, this Essay argues that both the President and Congress should decline the "invitation to struggle" that has marked U.S. foreign policy and national security policy for over two hundred years. Instead, the President should initiate a cooperative process to identify and prioritize the most likely intelligence targets of the next decade. When that process is complete, the President should propose a structure that will address the identified targets and accommodate the Intelligence Community's required flexibility. Congress should then approve or reject the proposed structure on an "up-or-down" basis. Part III also examines the pending proposal to establish the position of Director of National Intelligence and concludes that this proposal is flawed. This Essay then advances a few proposals that should be considered in restructuring the Intelligence Community.

\section{The Intelligence Challenge is Changing}

Over the last forty years, U.S. intelligence efforts have largely focused on two concerns. The first, and clearly most important, has been the military and political threat to the United States from the Soviet Union and its political satellites. Significant U.S. intelligence resources have been focused on Soviet military power, especially as a threat to European security. Eastern Europe has

3. It is a common mistake-one sometimes made even by senior government officials-to refer to the DCI as the "Director of the Central Intelligence Agency." 
been a window through which Soviet capabilities and intentions have been discerned. In addition, Soviet "adventurism" in other parts of the world has drawn U.S. intelligence interest chiefly on the basis of implications for the "East-West" power struggle.

The intelligence focus in other parts of the world has been primarily political. Most intelligence activities have been aimed at discerning information that sovereign states wish to keep secret and analyzing that information, together with other information, for the benefit of policymakers and diplomats. The nature of the collection and analysis may differ based on perceptions of whether a particular country is a "friend or foe," but the focus of intelligence activities has been on the political affairs of sovereign states. Lesser emphasis has been given to economic or social issues.

The U.S. Intelligence Community faces different, but no less daunting, challenges in the 1990's. Despite political reforms, Russia and the other Soviet republics continue to control the world's second most advanced arsenal of strategic nuclear weapons and the world's largest standing army. Economic and political upheaval in the Soviet Union have caused a level of instability unseen since 1918. At the same time, Soviet political and social reforms make information from this area far more plentiful than ever before. Yet, last summer's attempted coup ${ }^{4}$ and reciprocating disarmament proposals ${ }^{5}$ raise fundamental questions of whether intelligence efforts aimed at the Soviet Union will need to be redirected in the future, with less emphasis placed on Soviet military issues and more on economic and social issues.

More attention will also be accorded other regions and issues during the 1990's. Eastern and Central Europe are undergoing changes that seemed unthinkable little more than two years ago. Regional conflicts caused by religious, ethnic, or tribal rifts, such as those taking place in Central Europe, the Middle East, South Asia, and Africa can threaten U.S. interests. ${ }^{6}$ These conflicts take on added importance because of the continuing proliferation of weapons of mass destruction. Accordingly, the U.S. Intelligence Community of the 1990's requires a geographic breadth and depth well beyond its traditional focus. ${ }^{7}$

4. See, e.g., Francis X. Clines, The Soviet Crisis; Gorbachev is Ousted in an Apparent Coup by Soviet Armed Forces and Hard-Liners: Accused of Steering into a 'Blind Alley,' N.Y. TMES, Aug. 19, 1991, at Al.

5. See, e.g., Serge Schmemann, Bush's Arms Plan; Soviets Hail U.S. Arms Plan and Signal Their Own Cuts; Britain and France Join in, N.Y. TTMES, Sept. 29, 1991, § 1, at 1.

6. See generally Thomas L. Friedman, The Middle East Talks: New Talks, Old Words; Rivals Unsheathe Timeworn Swords, N.Y. TIMES, Nov. 1, 1991, at A8; Edward A. Gargan, Brutal Rebellion Pushing Northern Sri Lanka Back to a Pre-Industrial Era, N.Y. TIMES, Aug. 29, 1991, at A3; Jane Perlez, A New Chance for a Fractured Land, N.Y. TMES, Sept. 22, 1991, § 6, at 49 (describing ethnic tensions in the aftermath of Ethiopia's coup d'etat in May 1991); John Tagliabue, Old Tribal Rivalries in Eastern Europe Pose Threat of Infection, N.Y. TMES, Oct. 13, 1991, § 4, at 2.

7. See, e.g., H.R. REP. No. 65, 102d Cong., 1st Sess. 12-13 (1991) ("Operation Desert Shield/Desert Storm has taught us that we can no longer afford the luxury of concentrating so much of our intelligence resources on one possible adversary. Intelligence must have a baseline encyclopedic knowledge of the world 
The need to cover subjects beyond the traditional political and military focus of the Intelligence Community has increased. Policymakers have now begun to focus more intently on how economic developments affect U.S. competitiveness in international markets. ${ }^{8}$ Furthermore, counterterrorism, counternarcotics, technology transfer, and similar topics have been added to an already full platter of intelligence issues. Each of these subjects has major law enforcement components and transcends traditional political borders. Consequently, the Intelligence Community cannot approach these issues with conventional intelligence methods.

The Intelligence Community, however, must confront these increased demands with shrinking resources. The intelligence budget will, at best, stay the same for the near future, and it could be curtailed significantly as the defense budget is cut in response to the growth of the deficit and changes in the world. Policymakers will need to make important resource allocation decisions, some of which could profoundly affect the organization of the Intelligence Community, or at least the functions of some agencies.

Finally, the Intelligence Community must continue to improve coordination with policymakers in order to help chart the course that will best serve U.S. foreign policy interests. Because of their distinct roles, inherent tensions exist between intelligence officers and policymakers. While separation of roles is critical, intelligence officers must have an even greater understanding of the policymaking process and the value of intelligence in that process. Only in this way can intelligence remain relevant to the policymaking process. ${ }^{9}$

from which can be distilled rapidly, information to satisfy the needs of operational commanders.").

8. The importance of economic intelligence has been addressed by a number of current and former intelligence officials, including former DCI Stansfield Turner.

The most obvious specific impact of the new world order is that, except for Soviet nuclear weaponry, the preeminent threat to U.S. national security now lies in the economic sphere. The United States has turned from being a major creditor nation to the world's greatest debtor, and there are countless industries where U.S. companies are no longer competitive. We must, then, redefine "national security" by assigning economic strength greater prominence. That means we will need better economic intelligence. The United States does not want to be surprised by such worldwide developments as technological breakthroughs, new mercantilist strategies, sudden shortages of raw materials or unfair or illegal economic practices that disadvantage the country.

Stansfield Turner, Intelligence for a New World Order, 70 FOREIGN AFr. 150, 151 (1991); see also David L. Boren, The Winds of Change at the CIA, 101 YALE L.J. 853 (1992); William E. Colby, Intelligence in a New World, 1 MEDITERRANEAN Q. 46, 49-55 (1990).

9. The tension between policymaker and intelligence officer was described by Robert Gates when he was Deputy Director of Central Intelligence.

The fact is that, over the years, the policymaker and the intelligence officer have consistently (and with frighteningly few exceptions) come together hugely ignorant of the realities and complexities of each other's worlds-process, technique, form and culture. CIA officers can describe in excruciating detail how foreign policy is made in every country in the world save one-the United States.

Robert M. Gates, The CIA and American Foreign Policy, 66 FOREIGN AFF. 215, 219 (1987-88). As demonstrated by $\mathrm{Dr}$. Gates' recent confirmation hearings, however, intelligence agencies must be careful to maintain objectivity and to avoid charges of "politicizing" intelligence analysis. See Nomination Hearings: Divergent Portraits of Gates Presented by Witness, 49 CoNG. Q. 2901 (1991) [hereinafter Nomination Hearings]. 


\section{INTELligeNCE COMMUNITY AUTHORITIES AND RESPONSIBILITIES}

\section{A. Background on the Intelligence Community}

Defining the Intelligence Community's structure as it exists, much less as it should exist, is a difficult task. The Intelligence Community has little statutory basis. It is not defined, or even mentioned, in the National Security Act of 1947. The intelligence activities of the Treasury and State Departments and the military services, as well as the counterintelligence role of the FBI, predate the National Security Act. The formation of the CIA and the National Security Council (NSC) in 1947 provided a framework for an Intelligence Community, but little specificity. Even after the National Security Agency (NSA) was organized in 1952 and the Defense Intelligence Agency (DIA) was established in 1961, the Intelligence Community structure remained ill defined.

Since 1975, however, the Intelligence Community has operated under the guidance of a series of Executive orders dealing with intelligence activities. ${ }^{10}$ Each of these Executive orders addressed the structure of the Intelligence Community and the activities of Intelligence Community agencies to some extent. Executive Order 12,333, issued by President Reagan in 1981, currently governs the Intelligence Community's structure. ${ }^{11}$

Not surprisingly, the Intelligence Community's structure reflects the diversity inherent in the various agencies' areas of concern. ${ }^{12}$ Some agencies,

10. President Ford issued the first such Executive order in 1975. Exec. Order No. 11,905, 41 Fed. Reg. 7703 (1976). In 1977, President Carter replaced that Executive order. Exec. Order No. 12,036, 43 Fed. Reg. 3674 (1978).

11. Exec. Order No. 12,333, 3 C.F.R. 200 (1982), reprinted in 50 U.S.C. $\$ 401$ (1988). The current Executive order defines the Intelligence Community to include the following organizations:

1) The Central Intelligence Agency (CIA);

2) The National Security Agency (NSA);

3) The Defense Intelligence Agency (DIA);

4) The offices within the Department of Defense for the collection of specialized national foreign intelligence through reconnaissance programs;

5) The Bureau of Intelligence and Research (INR) of the Department of State;

6) The intelligence elements of the Army, Navy, Air Force, and Marine Corps, the Federal Bureau of Investigation (FBI), the Department of the Treasury, and, the Department of Energy; and,

7) The staff elements of the Director of Central Intelligence.

Id. For a more thorough description of the Intelligence Community and its agencies, see SCOTT D. BRECKENRIDGE, THE CIA AND THE U.S. INTELLIGENCE SYSTEM 40-53 (1986); see also James E. Meason, Military Intelligence and the American Citizen, 12 HARV. J.L. \& PUB. POL'Y 541, 547-54 (1989) (describing military intelligence agencies).

12. The agencies of the Intelligence Community conduct four basic intelligence functions. (1) Collection encompasses the gathering of information for use by policymakers. Much of the collection is from overt sources (e.g., media sources and government reports) or through diplomatic channels. Clandestine collection may come from human sources or by technical means such as satellites or electronic interception. (2) Analysis is the processing and interpretation of collected information into finished intelligence. (3) Counterintelligence involves those efforts aimed at preventing hostile foreign intelligence efforts from successfully obtaining information that the U.S. government does not want disclosed. (4) Covert action has recently been defined as any "activity or activities of the United States Government to influence political, economic, or military conditions abroad, where it is intended that the role of the United States Government will not be apparent or acknowledged publicly." Intelligence Authorization Act, Fiscal Year 1991, Pub. L. No. 102-88, 
like the DIA, focus almost entirely on military issues, and other Intelligence Community agencies expend significant resources on military issues. ${ }^{13}$ Some Intelligence Community agencies, however, consider military issues less important and have little interaction with those gathering military intelligence. These agencies tend to focus on political or economic issues.

Of all the agencies comprising the Intelligence Community, only the CIA reports directly to the President and has an independent mission established by statute. All other agencies report to one of five Cabinet secretaries and remain responsible for departmental missions. The majority of Intelligence Community agencies report to the Secretary of Defense. Yet each member of the Intelligence Community is also accountable, to some degree, to the DCI. This tension must be addressed in any Intelligence Community restructuring.

\section{B. DCI Authority}

The National Security Act fails to address specifically the DCI's authority to lead and direct the Intelligence Community. The DCl's powers emanate primarily from Executive orders, and to some extent from other Presidential directives. Hence, the DCI's authority is subject to change and interpretation by the President. Even if such authority were codified by statute, the effectiveness of any particular DCI is primarily dependent on the DCI's relationship with the President, the National Security Advisor, and the Secretaries of State and Defense.

Probably no DCI responsibility is more important than the Executive Order 12,333 's directive that the DCI "[a]ct as the primary adviser to the President and the [National Security Council] on national foreign intelligence." ${ }^{14}$ In Washington, where power is often measured more by the perception of access than by statutory authority, the manner in which the President permits the DCI to fulfill this responsibility is probably the paramount factor in assessing the DCI's ability to lead the Intelligence Community. The Executive order also provides that the $\mathrm{DCI}$ play a role in developing the Intelligence Community budget and in establishing the priorities for the Intelligence Community agencies. ${ }^{15}$

105 Stat. 429 (to be codified at 50 U.S.C. $\S 415$ ). This definition is similar, although not identical, to that contained in Executive Order No. 12,333.

13. The budgets of Intelligence Community agencies are classified, and therefore, the specific percentage of the budget expended on military issues is unavailable. Nevertheless, one commentator has concluded that the "Defense Department is actually the nation's primary producer of and consumer of intelligence information" with as much as $90 \%$ of the nation's intelligence resources under its control. Meason, supra note 11 , at $544 \&$ n. 12 .

14. Exec. Order No. 12,333, supra note 11, § 1.5(a).

15. Id. $\$ 1.5$. In addition, the Executive order charges the DCI with the following responsibilities:

[D]evelop . . . objectives and guidance for the Intelligence Community. . . . [P]romote the development and maintenance of services of common concern. . . . [F]ormulate policies concerning foreign intelligence and counterintelligence arrangements with foreign governments ... . [E]nsure the establishment . . . of common security and access standards. . . . [Develop programs] which protect intelligence sources, methods, and analytical procedures.... [E]stablish 


\section{The Role of Congressional Oversight}

Congress played only a limited role in the Intelligence Community structure from the late 1940's, when it enacted the National Security Act, until the mid1970 's. Over the last fifteen years, however, Congress has played a more active role in overseeing the activities of the Intelligence Community. This will undoubtedly continue as the President and Congress develop a new structure for the Intelligence Community.

\section{The Evolution of the Oversight Structure}

For many years, on the rare occasions when it was exercised, congressional oversight of the Intelligence Community was very informal.

For more than twenty-five years following the passage of the National Security Act, which created the Central Intelligence Agency in 1947, Congress largely ignored the [Tntelligence [C] ommunity .... It voted for untold billions of dollars in hidden appropriations for intelligence activities with very few, if any, of its members knowing either the amounts or the purposes of the funds. Members of Congress who were actively concerned about the activities of the [I]ntelligence [C]ommunity were rebuffed by large majorities on the few occasions when they tried to ask questions or to establish procedures for doing so. ${ }^{16}$

This congressional complacency began to change in the early 1970's when public allegations of CIA wrongdoing focused attention on the oversight issue. Congress launched investigations by the Senate Select Committee to Study Governmental Operations With Respect to Intelligence Activities, chaired by

uniform criteria for the determination of relative priorities for the transmission of critical national foreign intelligence. . . . [H]ave full responsibility for production and dissemination of national foreign intelligence. ... [E]nsure the timely exploitation and dissemination of data gathered by national foreign intelligence collection means. . . . [D]evelop . . . the consolidated National Foreign Intelligence Program budget. ... [R]eview and approve all requests for reprogramming ... funds. . . . conduct program and performance audits and evaluations . . . . [T] ogether with the Secretary of Defense, ensure that there is no unnecessary overlap between national foreign intelligence programs and Department of Defense intelligence programs ....

Id. For a recommendation that the DCI's authority in budget matters and intelligence tasking be enhanced, see infra notes 67-68 and accompanying text.

16. Cecll V. CrabB \& Pat M. Holt, invitation to Struggle: Congress, The President \& FOREIGN POLICY 163-64 (1989); see alsO AMERICAN BAR ASSOCIATION, OVERSIGHT AND ACCOUNTABILITY OF THE U.S. INTELLIGENCE AGENCIES-AN EVALUATION, A REPORT BY THE WORKING GROUP ON INTELLIGENCE OVERSIGHT AND ACCOUNTABILITY, TASK FORCE ON INTELLIGENCE AND COUNTERINTELLIGENCE 8 (1985) (before late 1970's, "a few members of the House and Senate Armed Services Committees and the Defense Subcommittees of the House and Senate Appropriations Committees had been the only members of the legislative branch exercising legislative oversight over the intelligence agencies. There had been no annual bills authorizing appropriations for the intelligence community, and there was no identifiable appropriation for intelligence."); GREGORY F. TREVERTON, COVERT ACTION: THE LIMITS OF INTERVENTION IN THE POSTWAR WORLD 75 (1987) (congressional "review of covert action was informal in the extreme"). 
Senator Frank Church, and by the House Select Committee on Intelligence, chaired by Representative Otis Pike. Both committees recommended that Congress establish permanent intelligence oversight committees. ${ }^{17}$

In response to these recommendations, Congress established the Senate Select Committee on Intelligence (SSCI) in 1976 and the House Permanent Select Committee on Intelligence (HPSCI) the next year. ${ }^{18}$ Almost immediately, these two committees began actively overseeing the Intelligence Community. Beginning with the Intelligence and Intelligence-Related Activities Authorization Act for Fiscal Year $1979,{ }^{19}$ the CIA and the other Intelligence Community agencies were subject to congressional authorization and appropriation procedures similar to other government agencies.

\section{Specific Reporting Requirements}

The core of congressional oversight is contained in sections 501 and 502 of the National Security Act, which was amended to its present form by the Intelligence Authorization Act, Fiscal Year 1991. ${ }^{20}$ Sections 501 and 502

17. Select COMM. TO STUdy GOVERNMENTAL OPERATIONS WITH RESPECT to INTElligence ACTIVITIES, FINAL REPORT, BOOK I, S. REP. NO. 755, 94th Cong., 2d Sess. (1976) (Church Committee). For example, the Church Committee concluded, inter alia, that its investigation:

underscores the need for an effective legislative oversight committee which has sufficient power to [balance the] fundamental conflicts between secrecy and democracy .... . [It is the Committee's view that effective congressional oversight requires the power to authorize the budgets of the national intelligence agencies. Without such authority, an oversight committee may find itself in possession of important secret information but unable to act effectively to protect the principles, integrity, and reputation of the United States.

S. REP. No. 755, at 424. See generally Kent A. Jordan, Note, The Extent of Independent Presidential Authority to Conduct Foreign Intelligence Activities, 72 GEO. L.J. 1855, 1862-63 (1984).

18. The SSCI was established by S. Res. 400, 94th Cong., 2d Sess., 122 CoNG. REC. 4754 (1976). The resolution directed the committee to "oversee and make continuing studies of the intelligence activities and programs of the United States Government, and to submit to the Senate appropriate proposals for legislation concerning such intelligence activities and programs." Id. $\S 1$.

The HPSCI was established by H.R. Res. 658, 95th Cong., 1st Sess., 123 CoNG. REC. 22,932 (1977). The resolution set forth the duties of the HPSCI in nearly identical terms as those contained in Senate Resolution 400.

19. Pub. L. No. 95-370, 92 Stat. 626 (1978).

20. Pub. L. No. 102-88, 105 Stat. 429 (1991) (to be codified at 50 U.S.C. § 413). The statute amended $\S 501$ of the National Security Act of 1947 and added $\S 502$. The Act now imposes the following reporting requirements on the President:

(a)(1) The President shall ensure that the intelligence committees are kept fully and currently informed of the intelligence activities of the United States, including any significant anticipated intelligence activity as required by this title.

....

(b) The President shall ensure that any illegal intelligence activity is reported promptly to the intelligence committees, as well as any corrective action that has been taken or is planned in connection with such illegal activity.

Pub. L. No. 102-88.

In addition, the Act requires the DCI, heads of all departments, and entities of the U.S. government to "keep the intelligence committees fully and currently informed of all intelligence activities." This section replaced similar requirements, applicable only to the $\mathrm{DCI}$, that had been enacted as part of the Intelligence Oversight Act of 1980, which was passed as title V of the Intelligence Authorization Act for Fiscal Year 1981, Pub. L. No. 96-450, § 501, 94 Stat. 1981 (1980). 
establish broad affirmative reporting requirements, most of which fall to the DCI. Thus, the DCI must keep the two intelligence committees "fully and currently informed of all intelligence activities" carried out by any U.S. government agency or department, "including any significant anticipated intelligence activity."21

The President must also "promptly" report "any illegal intelligence activity" and "any corrective action," and the DCI must report "any significant intelligence failure." In addition, the DCI must furnish any information or material "requested by either of the intelligence committees in order to carry out its authorized responsibilities."22 These requirements, in conjunction with a general spirit of cooperation, have resulted in a voluminous flow of information from the Intelligence Community to the oversight committees. Thus, during 1990, the CIA alone participated in over thirty hearings, provided over 1000 briefings to congressional committees and members, and furnished over 6000 reports and other analytical documents to Congress. ${ }^{23}$ In general, only the identity of sources and the details of technical operations are withheld from the intelligence committees in connection with their oversight responsibilities. ${ }^{24}$

The DCI's reporting requirements are subject to two exceptions. First, 50 U.S.C. $\S 413$ provides that the DCl's reporting shall be "consistent with due regard for the protection from unauthorized disclosure of classified information

21. Pub. L. No. 93-559, $\S 31,88$ Stat. $1795,1804-05$ (1974) (codified at 22 U.S.C. $\S 2422$ (1982)). The Hughes-Ryan Amendment, first passed by Congress in 1974, made the President accountable for all covert actions. As enacted, the amendment also required that covert actions for which a Presidential finding is obtained be reported in a timely fashion to the appropriate committees of the Congress. In total, there were eight congressional committees that had to be notified. In 1980 , simultaneously with passage of the Oversight Act, the Hughes-Ryan Amendment was amended to reduce the reporting requirements only to the intelligence committees, and to provide that covert actions are considered significant anticipated intelligence activities for purposes of $\S 501$. For a more extensive discussion of reporting requirements as they applied to CIA covert actions under the Hughes-Ryan Amendment, see Russell J. Bruemmer \& Marshall H. Silverberg, The Impact of the Iran-Contra Matter on Congressional Oversight of the CIA, 11 Hous. J. INT'L L. 219 (1988).

The Intelligence Authorization Act, Fiscal Year 1991 added a new $\S 503$ to the National Security Act of 1947, which established particular requirements for the approval and reporting of covert actions for the President and the DCI. The legislation was largely a codification of executive branch procedures established through National Security Decision Directive (NSDD) 286, issued by President Reagan in 1987. For a description of the unclassified portions of NSDD 286, see Bruemmer \& Silverberg, supra, at 235-36 (although entire document is classified, certain portions have been declassified and are on file with author). The Hughes-Ryan Amendment was explicitly repealed as part of the 1991 codification.

22. Pub. L. 102-88, 105 Stat. 429 (1991).

23. Telephone interview with CIA's Public Affairs Office, Oct. 11, 1991. This type of information flow caused then-DDCI Robert Gates to describe the CIA in 1987 as "involuntarily poised nearly equidistant between the executive and legislative branches." Gates, supra note 9, at 225 .

Covert actions, and the occasional controversy over the President's failure to report covert actions to Congress, have been the most significant exceptions to comity between the two branches of government on intelligence issues. Implementation of covert action is almost exclusively a CIA responsibility, see Exec. Order No. 12,333, supra note $11, \S 1.8(\mathrm{e})$, and even within the CIA, represents a very small percentage of resources expended. Thus, the vast majority of Intelligence Community activities are reported to and reviewed by Congress in a cooperative manner.

24. L. Britt Snider, Remarks of L. Britt Snider, 11 Hous. J. INT'L L. 47,49 (1988). 
relating to sensitive intelligence sources and methods."25 The section on covert action reporting specifically allows notice to be limited "[i]] the President determines it is essential to limit prior notice to meet extraordinary circumstances affecting vital interests of the United States." ${ }^{26}$ This provision addresses executive branch concerns that some intelligence information is too sensitive to share with all of the members of the two committees. As a practical matter, however, this provision has not been used by the executive branch to limit prior notice.

The second exception to the prior notice requirement results from the tension between the President and the Congress over their respective constitutional roles in the conduct of foreign policy. ${ }^{27}$ The President undoubtedly will continue to assert his inherent constitutional authority to withhold some information on the conduct of intelligence activities from Congress. ${ }^{28} \mathrm{He}$ is likely to assert that this constitutional authority can be exercised independently of any statutory limitations. ${ }^{29}$ Congress understandably will not accept this argu-

25. 50 U.S.C. $\$ 413$ (1988). The Act explicitly states that this provision "shall [not] be construed as authority to withhold information from the intelligence committees on the grounds that providing the information ... would constitute the unauthorized disclosure of classified information or information relating to intelligence sources or methods." Id. \$ 413(e). This caveat leaves open the possibility that "exceptionally sensitive matters" might be withheld from the committees.

26. $1 d$. $\$ 413$. In such circumstances, the President may restrict notification to the "the chairmen and ranking minority members of the intelligence committees, the Speaker and the minority leader of the House of Representatives, and the majority and minority leaders of the Senate." Id.

27. See generally infra notes $31-39$ and accompanying text. The preamble to former $\$ 501$ explicitly referred to the "applicable authorities and duties ... conferred by the Constitution upon the executive and legislative branches of the Government. ..." 50 U.S.C. \$ 413(a), repealed by Intelligence Authorization Act, Fiscal Year 1991, Pub. L. No. 102-88, § 602(a)(2), 100 Stat. 429, 441. For a discussion of the preamble's language and the resulting compromise on this issue during the enactment of the Intelligence Oversight Act of 1980, see Bruemmer \& Silverberg, supra note 21, at 227-28.

28. In his signing statement on the Intelligence Authorization Act, Fiscal Year 1991, President Bush said:

Several provisions in the Act requiring the disclosure of certain information to the Congress raise constitutional concerns. These provisions cannot be construed to detract from the President's constitutional authority to withhold information the disclosure of which could significantly impair foreign relations, the national security, the deliberative processes of the Executive, or the performance of the Executive's constitutional duties.

Signing Statement, Intelligence Authorization Act, Fiscal Year 1991, reprinted in 27 WEEKLY COMP. PRES. DoC. 1137, 1138 (Aug. 14, 1991).

29. Cf. Presidential Power to Use the Armed Forces Abroad Without Statutory Authorization, 4A Op. Off. Legal Counsel 195-96 (1980); Legal Opinion of May 9, 1980, by Lloyd Cutler, Counsel to the President on War Powers Consultation Relative to the Iran Rescue Mission (on file with author). 
ment. ${ }^{30}$ This constitutional quandary must be considered as the President and Congress move to restructure the Intelligence Community.

\section{A PROPOSAL FOR REORGANIZATION}

The need for restructuring the Intelligence Community is overwhelming. As set forth above, the Intelligence Community will face a variety of matters that have not been within its traditional focus. A shift away from the Soviet military/political orientation that shapes and dominates its structure will likely be required. Any restructuring must be designed so that the Intelligence Community is left with the necessary flexibility to address the regional, economic, and other issues of interest to the United States that were described in Part I of this Essay.

Congress and the executive branch appear to agree that a review of the Intelligence Community's structure is necessary. Both congressional intelligence committees, the DCI, and the Secretary of Defense have begun efforts aimed at restructuring the Intelligence Community. What remains to be determined is which structure is best suited for fulfilling the U.S. government's future intelligence needs.

30. The tension is described in the conference committee report accompanying the Fiscal Year 1991 Intelligence Authorization Bill:

At the same time, however, it is the intent of the conferees that this provision be interpreted in a manner consistent with whatever authority the Constitution may provide. If the Constitution in fact provides the President authority to withhold notice of covert actions for longer periods, then the conferees' interpretation cannot be legally binding upon the President. In his letter to the committees, reprinted above, the President asserts that the Constitution, in his view does provide such authority.

Neither committee has ever accepted this assertion. The conferees recognize that this is a question that neither they nor the Congress itself can resolve. Congress cannot diminish by statute powers that are granted by the Constitution. Nor can either the legislative or executive branch authoritatively interpret the Constitution, which is the exclusive province of the judicial branch.

JOINT EXPLANATORY STATEMENT OF THE COMM. OF CONFERENCE, INTELLIGENCE AUTHORIZATION ACT, FISCAL YEAR 1991, REP. No. 166, 102d Cong., 1st Sess. 28 (1991). 


\section{A. Principles of the Proposal}

\section{Joint Action Is Preferable}

An analysis of Intelligence Community reorganization must begin by noting that neither the President nor Congress can claim sole authority on foreign policy and national security issues. Scholars and politicians have struggled to construct a framework for decisionmaking in these areas, but largely without success. Instead, we are left with a situation best described by Professor Corwin's oft-quoted observation: "[T]he Constitution, considered only for its affirmative grants of powers capable of affecting the issue, is an invitation to struggle for the privilege of directing American foreign policy." ${ }^{\text {"31 }}$ Certainly this adage retains its truth when the term "national security" is substituted for "foreign policy."

In some areas affecting foreign policy and national security-the power to grant or withhold diplomatic recognition and to classify and control information-the authority of the President is generally preeminent. On the other hand, Congress controls most funding for intelligence activities through its appropriations power. In most areas, such as national security, however, the two branches struggle for dominance, and little guidance is provided by the judiciary in determining which branch should have the upper hand..$^{32}$

The "invitation to struggle" over national security issues should be declined whenever possible. The ineffectiveness of the War Powers Resolution ${ }^{33}$ serves as a vivid illustration of the unfortunate consequences that can result when the President and Congress vehemently adhere to principle and thereby fail to reach consensus on a national policy issue. Not surprisingly, it is difficult to find anyone who believes that U.S. national security interests are strengthened by the current version of the War Powers Resolution, which was passed over President Nixon's veto in 1972, and has remained a source of conflict between the President and Congress ever since. ${ }^{34}$

31. EDWARD S. CORWIN ET AL, THE PREsIDENT: OFFICE AND POWERS, 1787-1984, at 201 (5th rev. ed. 1984).

32. Professor Koh argues that the reluctance of the Supreme Court and the lower courts to intervene in foreign policy decisionmaking takes two forms: the Court either grants the President undue deference with respect to foreign policy decisions or refuses to hear challenges to the President's authority for lack of justiciability or standing. See HAROLD H. KOH, THE NATIONAL SECURITY CONSTITUTION 134-49 (1990). The former is exemplified by Dames \& Moore v. Regan, 453 U.S. 654 (1981), and United States v. CurtissWright Export Corp., 299 U.S. 304 (1936). The latter is exemplified by Burke v. Barnes, 479 U.S. 361 (1987), and Goldwater v. Carter, 444 U.S. 996 (1979).

33. War Powers Resolution of 1973, Pub. L. No. 93-148, 87 Stat. 555 (codified at 50 U.S.C. $\$ \S 1541-$ 48 (1988)) (placing limits on ability of President to deploy U.S. troops into hostile situations and requiring that President consult Congress about such deployment).

34. Criticism of the War Powers Resolution is rampant, as are proposals for correcting its failures. See, e.g., John H. Ely, Suppose Congress Wanted a War Powers Act That Worked, 88 CoLUM. L. REV. 1379 (1988); Cyrus R. Vance, Striking the Balance: Congress and the President Under the War Powers Resolution, 133 U. PA. L. REV. 79 (1984). One commentator after noting that neither the President, the courts, nor Congress has complied with or enforced the War Powers provisions, concluded that "[f]or the 
A more viable model for resolving national security issues, such as restructuring the Intelligence Community, is set forth in Justice Jackson's concurrence in Youngstown Steel Co. v. Sawyer. ${ }^{35}$ The idea is expressed succinctly by Judge Mikva: The executive branch "acts at the apex of its power ... [when] it wields the combined power of both the executive and legislative branches." ${ }^{36}$ Thus, both Congress and the President should approach Intelligence Community restructuring with the view that neither will impose its solution for restructuring on the other.

\section{The President Should Take the Lead}

Considerable energy could be wasted, and comity displaced, by arguing over who should initiate a proposal for changing Intelligence Community structure. Congress might view itself as leading this issue and believe that its collective wisdom can provide the best answer to the question. Congress might even believe that no substantial change will be effected unless it acts. Nonetheless, conscious of my previous argument that reorganization should be a shared responsibility, the structure of the Intelligence Community is an issue on which the President's views should energize the debate and should be entitled to greater weight.

To understand why the executive branch should hold sway in this struggle, one must appreciate that intelligence is not a good or service with an inherent, intrinsic value. Instead, intelligence is only a tool in the process that formulates U.S. national security and foreign policy. The task of establishing that policy falls primarily, or at least initially, on the executive branch. As noted by one commentator:

[I]n the United States system the executive branch as a whole is more likely to obtain a correct understanding of international political reality. In this area, the President's chief task is to get the accurate information

most part, the law has been treated by everyone as if it were a potted plant." Thomas M. Franck, Special Issue: The United States Constitution in Its Third Century: Foreign Affairs: Distribution of Constitutional Authority: Rethinking War Powers: By Law or By "Thaumaturgic Invocation?," 83 AM. J. INT'L L. 766, 769 (1989).

35. 343 U.S. 579 (1952). Justice Jackson explained that:

1. When the President acts pursuant to an express or implied authorization of Congress, his authority is at its maximum. ...

2. When the President acts in the absence of either a congressional grant or denial of authority, he can only rely upon his own independent powers, but there is a zone of twilight in which he and Congress may have concurrent authority, or in which its distribution is uncertain....

3. When the President takes measures incompatible with the expressed or implied will of Congress, his power is at its lowest ebb, for then he can rely only upon his own constitutional powers minus any constitutional powers of Congress over the matter.

343 U.S. at 634 (Jackson, J., concurring).

36. Palestine Info. Office v. Schultz, 853 F.2d 932, 937 (D.C. Cir. 1988) (Mikva, J.); see also Dames \& Moore, 453 U.S. at 668-69. 
about other nations that already exists within the executive branch into the hands and minds of key decisionmakers before they must act. ${ }^{37}$

To be sure, Congress has a role in forming U.S. foreign and national security policy, but its role is more appropriately a secondary one of oversight and review.

Recent history shows that the executive branch is most often in the position of defining the debate and action on foreign policy issues. ${ }^{38}$ It is the President who must be prepared to act in a crisis situation and who must have information that requires immediate action. The President must respond to attacks on U.S. interests and protect or rescue American citizens endangered by coups or civil wars. The President also must be prepared to grant or withhold diplomatic recognition to emerging governments or to withdraw recognition in appropriate circumstances.

Intelligence is a critical tool in shaping such responses. Congress may conduct a postmortem to determine if a given crisis was an "intelligence failure" or if the President's foreign policy contributed to or failed to respond adequately to the crisis. Moreover, if the situation lasts long enough, and especially if appropriations are necessary to sustain the U.S. response, Congress will almost certainly assert (if the President does not otherwise request) a consultative role. Nevertheless, it is the President and the executive branch who must act in those moments when the situation requires immediate access to information.

Finally, as experience has demonstrated, the structure of the Intelligence Community should have flexibility to adapt to the personal characteristics of the President. Some Presidents have actively used intelligence. President Bush, like President Ford did, receives daily intelligence briefings directly from the CIA. Other Presidents, including Presidents Reagan and Carter, have generally used their National Security Advisors to synthesize intelligence information. In some administrations, there has been a competitive atmosphere among the CIA, the various departments, and the National Security Council. ${ }^{39}$ In the

37. P. Edward Haley, Legislative-Executive Relations and the United States Intelligence Community, 12 HARV. J.L. \& PUB. POL'Y 495, 501 (1989).

38. After considering the structural basis on which the struggle between Congress and the President is waged, Professor Corwin notes:

Not only is a struggle for power in this field thus invited; in the absence of a co-operative disposition all around it is well-nigh inevitable. Nor do the applicable principles of constitutional law help much in resolving such a quarrel.... Even so, if our diplomacy was to have a reasonable chance of success in the world at large it had to have unity of direction from an organ of government that was "always in session," which could act swiftly and secretly, and that commanded the widest information; and these requirements the Presidency met.

CORWIN ET AL. supra note 31, at 255. Even those who argue that the Framers intended Congress to have a broader role acknowledge that the President has achieved preeminence in foreign policy decisionmaking. See, e.g., Louis Henkin, Foreign Affairs and the Constitution, 66 FOREIGN AFF. 284, 291-92 (1987).

39. The evolving role of the National Security Advisor and the tension between roles of the National Security Council Staff and other intelligence departments and agencies is discussed, inter alia, in KOH, supro note 32, at 53-57; see also REPORT OF THE PRESIDENT's SPECIAL REVIEW BOARD, at II-2 to II-4 (1987) 
current administration, the model is largely one of collaboration. The Intelligence Community's structure must fit these personal characteristics.

It should be apparent from these considerations that, as the primary user of intelligence, the President's views also should be entitled to a greater, or at least the initial, voice in how the Intelligence Community should be structured. It is the President who will have a better understanding of how the Intelligence Community structure will fit in with the executive branch's foreign policymaking apparatus. The President will be held most directly accountable for any failures caused by inefficiencies in the Intelligence Community structure. Moreover, it is the President, in the capacity of the unitary executive, who is more likely to be able to move quickly and consistently to propose and implement a restructuring proposal.

\section{A Consensus on Reorganization Must Be Developed}

Reorganization in a vacuum, or even in response to the "last war" (no matter how recent), is likely to confuse motion with progress. A meaningful restructuring proposal can only result from a determination of three first-order objectives against which the Intelligence Community's success will be measured. Without general agreement about these first-order objectives, perceptions about the success of any reorganization could vary greatly. Therefore, the process by which these objectives are established must include the Intelligence Community, military leadership, and Congress.

The first objective to be identified is which targets and threats the Intelligence Community will monitor during the next decade. In the past, making this determination was easy. For over forty years, the primary focus of the Intelligence Community was the military and political activities of the Soviet Union and its satellites. As explained earlier, the Intelligence Community must now cover a broader range of issues across the globe. ${ }^{40}$

Most importantly, this review of targets and threats should look beyond the immediate future. The annual budget cycle adequately identifies short-term threats and allocates resources to meet them. The budget process, however, is not geared to accommodate intelligence threats throughout the next decade. Assessing threats in order to design the optimal Intelligence Community structure demands a long-range view.

The second basic objective to be determined is which priorities will be assigned to these intelligence targets. In the past, there have always been more intelligence targets than resources to cover them. This disparity will become even greater in the 1990's given the intelligence requirements and budget constraints the Intelligence Community will face. Only a clear sense of priori-

(generally called the "Tower Commission" report).

40. See supra notes $6-8$ and accompanying text. 
ties will enable the Intelligence Community to attack these issues in an effective manner.

Finally, Congress and the President must reach a consensus about the level of funding that will be available to address these prioritized targets. The current budget system is dependent on yearly authorization and appropriation cycles. Some multiyear funding is provided for certain projects, but intermittent funding, or even uncertainty over funding, can seriously undermine intelligence programs. Thus, the objective to be determined is what level of resources is likely to be available to address the prioritized intelligence targets.

\section{Piecemeal Reorganization Should be Avoided}

Piecemeal solutions are not likely to provide an overall structure that will best serve the government's long term national security interests. Instead, the President and Congress should seek a broad-based, more lasting solution. Nevertheless, both the Senate and the House of Representatives have recently proposed piecemeal solutions to this complex situation..$^{41}$ The Department of Defense has also approved a reorganization plan that addresses some, but not all, of the issues that should be considered in restructuring the relationship between military and nonmilitary intelligence agencies. ${ }^{42}$ Because piecemeal solutions are not likely to result in the most effective Intelligence Community structure, these proposals, each of which has some merit, should be considered as part of a more comprehensive review.

The SSCI report attempts to solve the perceived problems with the CIA's human intelligence support to the military during Desert Storm. It requires the CIA to create an additional Associate Deputy Director for Operations (ADDO) specifically for military operations. The newly created ADDO would be a flagrank military officer who would "ensure that military requirements are fairly represented within CIA" and would "advocate an earlier and more effective interaction by CIA with DoD operational planners." ${ }^{\text {"43 }}$ In addition, the SSCI report requires the Assistant Secretary of Defense for Command, Control, Communications, and Intelligence (ASD/C3D) to appoint an imagery manager to "ensure that all DoD imagery systems adhere to a common set of standards." 44 Exercising budget authority over the various DoD imagery components, the imagery manager would address problems in imagery dissemination identified by the report.

41. See S. REP. No. 117, 102d Cong., 1st Sess. 4-5 (1991); H. REP. No. 65, supra note 7, at 4-6.

42. Assistant Secretary of Defense (Command, Control, Communications, and Intelligence), Plan for Restructuring Defense Intelligence (Mar. 15, 1991) (unpublished, declassified government document on file with author).

43. S. REP. No. 117 , supra note 41 , at 6 .

44. Id. 
Each idea attempts to impose a solution at the top of bureaucracies that themselves may require more fundamental changes to address the perceived problems. For example, the CIA's intelligence collection to support the military might be better improved by requiring a career military officer to fill one of the two or three senior positions in the Intelligence Community ${ }^{45}$ or by increasing interagency assignments between the military intelligence services and the CIA's divisions responsible for human intelligence collection. Similarly, improvements in coordinating imagery collection and exploitation should be implemented across the Intelligence Community, not just within the Defense Department.

The SSCI's "requirements" also illustrate another basic problem. As is often the case, significant Intelligence Community changes would be implemented as part of the congressional authorization process and not in independent legislation. Moreover, the SSCI's "requirements" are contained only in the report accompanying the Authorization Act and not in the Authorization Act itself. The legal and practical efficacy of such "requirements" is uncertain. They are, of course, not "presented" to the President, nor are they subject to presidential veto, which may run afoul of INS v. Chadha ${ }^{46}$ and other similar cases. As a practical matter, enactment through report language also limits the debate on such matters. Robust debate not only sharpens the result, but also enhances the legitimacy of any changes that are made. ${ }^{47}$

The House 1992 Intelligence Authorization Bill Report also advocates a similar piecemeal approach in response to perceived weaknesses in the Intelligence Community structure. The House report "recommends" the transfer of DoD science and technology intelligence assets to the DIA and requires the ASD/C3I to report to Congress on the status of these recommendations. ${ }^{48}$ The report also encourages improvements in the use of the Intelligence Community staff $^{49}$ and recommends withholding a portion of the Intelligence Community staff's budget until the DCI submits plans to improve the staff's management efficiency. 50

The executive branch must also accept some blame on this score. The Secretary of Defense, for instance, recently approved a reorganization plan for DoD intelligence activities. The DoD plan consolidates responsibility for most

45. See infra Part III.B.2.

46. 462 U.S. 919 (1983) (holding legislative vetoes unconstitutional).

47. By "enacting" requirements through report language, Congress might be seen to have won the "struggle" because the President cannot veto the requirement and the agencies must, as a practical matter, follow the requirement or face the wrath of Congress. However, as one commentator has aptly commented on Professor Corwin's "invitation to struggle" quotation: "[T]he objective of the struggle is not control but wise policies acceptable to the American people." Alton Frye, Congress and President: The Balance Wheels of American Foreign Policy, 69 YALE REV. 1, 2 (1979).

48. H. REP. NO. 65 , supra note 7 , at 7-9.

49. The Intelligence Community staff is drawn from the Intelligence Community agencies and assists in coordinating budget and other resource issues for the DCI. It reports directly to the DCI and is headed by the Director of the Intelligence Community Staff.

50. H. REP. No. 65, supra note 7, at 9-11. 
of the DoD intelligence effort in the ASD/C3I, a move that was not instituted in conjunction with any possible restructuring of the nonmilitary intelligence agencies. The HPSCI has already criticized the reorganization plan for not implementing a sufficiently broad restructuring. ${ }^{51}$ The Senate Armed Services Committee also has expressed strong disagreement with the plan's shift of the Director of DIA's reporting responsibility to the ASD/C3I.52 While it is too early to determine the plan's effectiveness, it is clear that the DoD reorganization may need to be reconsidered in light of other restructuring proposals.

\section{Congress Should Proceed by Up-or-Down Vote}

The President might assert that any Intelligence Community reorganization could, and should, be effected solely through Executive order or other Presidential directive. As noted above, it is the executive branch that plays the larger role in the structure and effectiveness of the Intelligence Community. Nonetheless, the President and the Intelligence Community would be well served by involving Congress in any restructuring, provided that congressional involvement does not lead to unduly prolonged consideration or tinkering of the sort that led, in part, to the demise of legislation efforts (the "Charter Legislation") to regulate the Intelligence Community in the late 1970's. ${ }^{53}$

Efforts to enact the Charter Legislation demonstrated the practical difficulties in attempting to address Intelligence Community restructuring through the traditional legislative process. The Charter Legislation would have created statutory charters for a number of Intelligence Community agencies. Both the Congress and the President supported this effort in principle, but after almost four years of legislative proceedings, the Congress and the Carter Administration could not reach agreement on a comprehensive proposal for the Intelligence Community's structure. Indeed, the Administration ended up opposing efforts to codify many of the provisions of its own Executive order on intelligence activities. $^{54}$

Over time, there have been a number of instances in which Congress has been willing to forego its traditional legislative role and instead approve or reject an executive branch proposal on an "up-or-down" basis. The Executive Reorganization Act ${ }^{55}$ and "fast-track" approval for trade agreements ${ }^{56}$ are

51. Id.

52. S. REP. No. 113, 102d Cong., 1st Sess. 273-75 (1991).

53. The first such bill was the National Intelligence Reorganization and Reform Act of 1978, S. 2525 , 95th Cong., 2d Sess. (1978). An identical bill was H.R. 11,245, 95th Cong., 2d Sess. (1978). Similar legislation was considered in the next Congress as S. 2284, 96th Cong., 2d Sess. (1980). See genterally JoHN M. OSETH, REgULATING U.S. INTELligenCE OPERATIONS 122-148 (1985); Newell L. Highsmith, Note, Policing Executive Adventurism: Congressional Oversight of Military and Paramilitary Operations, 19 HARV. J. ON LEGIS. 327, 354-64 (1982).

54. See Highsmith, supra note 53 , at 357 .

55. 5 U.S.C. $\S \S 901-912$ (1988). The Executive Reorganization Act, which was enacted in 1966, requires the President to transmit a "reorganization plan" to Congress whenever the President determines 
two examples. However, both the Executive Reorganization Act and fast-track agreement authority have weaknesses in certain circumstances because neither is triggered until the President presents a proposal to Congress. Moreover, an affirmative congressional approval is required before a presidential plan can be implemented.

Therefore, the procedure recently used to consider and approve military base closings provides a better model to follow. Under the Defense Base Closure and Realignment Act of 1990,57 the Secretary of Defense is required to submit to Congress a description of planned troop deployments along with the selection criteria proposed for evaluating recommendations for closure or realignment. Using this system, the reasoning underlying any decisions are understood by both Congress and the executive branch before the decisions are made. The Secretary then publishes a list of recommended closures and realignments and transmits that list to a commission appointed by the President and confirmed by the Senate. The commission reviews the Secretary's recommendations and submits a report to the President with the commission's own recommendations. If the President agrees with the Commission's recommendations, the President transmits a report to Congress. The Secretary of Defense then carries out the base closures recommended by the commission and approved by the President, unless Congress passes a joint resolution disapproving the recommendations within forty-five days of the President's transmittal. The joint resolution is subject to expedited consideration that assures a vote on the motion to disapprove within the forty-five day time period.

The Base Closure Act assures Congress that difficult issues will be considered, and considered in an orderly manner, using a process designed to elicit as much information as possible. When presented with a proposal under the Act, Congress must conduct an up-or-down vote in a short period of time. It thus has ample opportunity to review proposals without having the time to

that "changes in the organization of agencies are necessary" to promote more effective management of the executive branch or increase efficiency in the government. Id. $\S 903$. The plan may provide for transfer or consolidation of functions, and even the abolition of an agency if the functions of that agency have been transferred to another agency.

Once transmitted, the plan proceeds on a timetable that virtually assures an up-or-down vote within 90 days. The plan is referred to the Senate Government Affairs Committee and the House Government Operations Committee, which must consider the plan within 75 days. A resolution disapproving the plan may then be brought up for consideration by any member of either house. Debate is limited (10 hours total), and no amendments or reconsideration are permitted.

Under the pre-1984 version of the Executive Reorganization Act, a veto by either house would make the President's reorganization proposal ineffective. 5 U.S.C. $\$ 909$ (1982), amended by Pub. L. No. 98-614, $\S 3$ (c), 98 Stat. 3192 (1984). In 1983, however, the Supreme Court held that legislative vetoes are unconstitutional in INS v. Chadha, 462 U.S. 919 (1983). In response to Chadha, Congress amended the Reorganization Act in 1984. The amendment requires both houses to approve a reorganization proposal for it to become effective and extends the time period for congressional action from 60 to 90 days.

56. Professor Koh offers "fast-track approval," such as that used to approve trade agreements, as a model for foreign affairs legislation. See $\mathrm{KOH}$, supra note 32 , at 176 . This type of procedure also might be used to involve Congress in intelligence matters. The prime example of the fast-track model, the Trade Act of 1974, 19 U.S.C. $\S \S 2101-2495$ (1988), is procedurally similar to the Reorganization Act.

57. Pub. L. No. 101-510, $\$ 2901-2910,104$ Stat. 1808 (to be codified at 10 U.S.C. $\S 2687$ note). 
consider and debate up to 535 views on the subjects. Unlike the experience with Charter Legislation, hard choices and difficult compromises will not result in extended delay or failure.

\section{B. Specific Proposals for Restructuring}

What structure, then, should result from this process? One model, largely a repeat of proposals that have appeared over the years, is pending in the Senate. That proposal, which is described in the Section A of this part, has flaws, and is unlikely to improve the functioning of the Intelligence Community. This section describes alternative proposals to restructure the Intelligence Community.

\section{Proposal to Create a Director of National Intelligence}

Over the years, a number of proposals would have created a Director of National Intelligence (DNI) to function as the head of the Intelligence Community and as the President's senior intelligence adviser, but who would neither manage nor direct the CIA. ${ }^{58}$ One such proposal appeared in the Charter Legislation. ${ }^{59}$ This proposal has resurfaced in a bill currently before the Senate that would split the current DCI's responsibilities between a DNI and a Director of the CIA, while assigning each a deputy ${ }^{60}$ All four positions would be appointed by the President and confirmed by the Senate.

The DNI would be a member of the National Security Council and, by statute, would be designated as "the nation's senior intelligence officer and primary adviser to the President on foreign intelligence matters." ${ }^{11}$ While the duties of the DNI would encompass many of the same areas covered by Executive Order 12,333, the language used in the statute is more explicit. The role of the Director of the CIA would be diminished accordingly. The Director of the CIA would report to both the National Security Council and the DNI. This framework includes some organizational shifts in the Intelligence Community structure that would provide the DNI with a staff to run the Intelligence Community.

Advocates of the DNI proposal argue that the current DCI is unduly influenced by the CIA. ${ }^{62}$ The DNI, they argue, would bring more objectivity to the intelligence process and would facilitate programmatic and resource tradeoffs across agency lines. Furthermore, the DNI would have the advantage

58. See generally John Prados, Intelligence Community Leadership: Development and Debate Since 1947, at 37-52 (June 27, 1989) (study on file with Congressional Research Service).

59. See supra note 53 .

60. S. $421,102 d$ Cong., 1st Sess. (1991).

61. Id. \$ 3 .

62. See, e.g., Turner, supra note 8 , at 164-66. 
of being free from any bias created by allegiance to a single agency. Supporters also assert that the demands of managing and directing the CIA detract from the DCI's ability to advise the President and manage the Intelligence Community.

The benefits generated from creating a DNI divested of management responsibility for a single agency-in effect, an "Intelligence Czar"-would fail to outweigh the potential diminution in the quality and responsiveness of intelligence. The DCI currently draws on a wealth of substantive intelligence support from the CIA. A DNI either would be removed from this support or would have to replicate it through new sources. In addition, a DNI would duplicate many of the intelligence functions performed by the National Security Adviser, creating a potential for confusion and tension within both the Intelligence Community and the national security policymaking apparatus. It is highly probable that a DNI would eventually command the Intelligence Community in name only. Thus, the creation of such a position would ill serve the President, the Congress, and the Intelligence Community. In fact, most DCI's have opposed the creation of a DNI. ${ }^{63}$

\section{Proposed Elements for Restructuring}

A definitive reorganization framework cannot be proposed until the process described in Part III.A is complete, and, more importantly, the bases on which reorganization will proceed are clear. Even so, there are certain elements that are important to consider in any restructuring plan.

As noted above, the DCI should continue to be the administrative head of the CIA. In any reorganization, the CIA is likely to remain the primary focal point for the kind of broad-based intelligence collection and analysis required by policymakers, with the other Intelligence Community agencies having more limited and focused roles. A direct role in the CIA's management and an ability to draw on the CIA's substantive intelligence support will better enable the DCI to serve as the President's primary intelligence adviser.

Given the evolving nature of intelligence requirements, Congress should consider, however, including offices from other agencies within the Intelligence Community, and hence, making them subject to the DCI's guidance and direction. For example, certain activities of the Department of Commerce and the Office of the U.S. Trade Representative have a direct bearing on the economic issues that will likely receive increased intelligence emphasis. The Environmen-

63. The Carter Administration's support of the Charter Legislation would have resulted in a DNI-like structure, but the DNI would have continued to manage the CIA. President's Carter's DCI, Stansfield Turner, continues to support the DNI concept. See id. at 164-66. In 1978, each of Admiral Turner's two predecessors, Richard Helms and George Bush, testified in opposition to the proposal. National Intelligence Reorganization and Reform Act of 1978: Hearings on S. 2525 Before the Senate Select Comm. on Intelligence, 95th Cong., 2d Sess. 46-47, 211-12 (1978). Based on discussions with former DCI's Richard Helms, William Colby, and William Webster, I believe that each of them continues to oppose the DNI concept. 
tal Protection Agency might merit inclusion as international environmental issues grow in prominence from the standpoint of the Intelligence Community. The DCI could coordinate these activities more effectively if these offices were included in the Intelligence Community. Moreover, including the Drug Enforcement Agency (DEA) and the FBI's international counternarcotics and counterterrorism efforts within the Intelligence Community deserves consideration as these law enforcement issues receive greater intelligence emphasis. ${ }^{64}$

One of the more significant challenges facing the DCI will be enhancing coordination among Intelligence Community agencies-especially between military and nonmilitary agencies. This issue was addressed in each of the recent Senate and House authorization bill reports. Perhaps this is a logical (if not inevitable) byproduct of the significantly larger intelligence budgets of the 1980's. In an era of abundant resources, redundancies within the Intelligence Community were more easily tolerated; it was probably easier for an agency to obtain appropriations to meet a perceived need than to convince another agency to meet that same need. The 1990's, however, will require the President and the DCI to insist on greater coordination and cooperation among the Intelligence Community agencies as intelligence requirements increase but budget resources shrink.

Most DCI's have found that the demands of the multifaceted position require them to rely on the Deputy Director of Central Intelligence (DDCI) for significant functions. Depending on the DDCl's experience, these delegated duties may pertain primarily to managing the Intelligence Community or to managing the CIA. In light of the sweeping changes in the Intelligence Community, it would be worthwhile to consider reinstituting two DDCI's, a structure that worked when President Bush was DCI in the mid-1970's. One DDCI could then focus on assisting the DCI in his role as head of the CIA, in effect becoming chief operating officer of the CIA. The other could focus on the DCI's Intelligence Community responsibilities, assisting in the coordination and resource allocation decisions that will be so important in the next decade.

If the two-DDCI structure is adopted, one of the Intelligence Community's three top positions should be held by a current or retired military officer. Current law prohibits both the DCI and the DDCI from being military officers. ${ }^{65}$ Since 1947 , however, either the DCI or the DDCI position often has been very effectively filled by an active duty or retired military officer. Especially with reduced Intelligence Community resources, the importance of promoting cooperation between military intelligence components and the other Intelligence Community agencies cannot be underestimated. Having a military officer in a position of senior leadership within the Intelligence Community

64. Portions of the DEA are already included within the intelligence authorization bills for budget purposes, and President Carter's Executive order included the DEA as a member of the Intelligence Community. Exec. Order No. 12,036, supra note 10, § 1-15.

65. 50 U.S.C. § 403(a) (1988). 
might be an effective means to encourage such cooperation. Moreover, a military officer serving as DCI or DDCI would promote cooperation between the CIA and the military services even more effectively than would the military Associate Deputy Director for Operations required by the SSCI authorization bill report. ${ }^{66}$

If the $\mathrm{DCI}$ is to ensure increased flexibility and reduce redundancy and inefficiency within the entire Intelligence Community, additional powers should also be considered. For example, the Carter Executive order endowed the DCI with "full and exclusive authority" to approve the budgets of Intelligence Community agencies. ${ }^{67}$ In effect, this language gave the DCI a trump over the Secretary of Defense on Intelligence Community budget issues. This explicit authority would enable the DCI to control Intelligence Community expenditures more effectively. Similarly, the DCI's authority to establish intelligence collection requirements-currently phrased in terms of "establish[ing] mechanisms" and "resolv[ing] conflicts" ${ }^{\text {_ }}$-should be redrafted in terms that give the DCI more explicit authority to direct the collection activities of the various agencies of the Intelligence Community. Other ways to enhance the DCI's authority also merit consideration.

The possibility of switching the roles of the DCI and the Secretary of Defense in the selection and direct supervision of the Directors of the NSA and the DIA should also be considered. Currently, because both agencies are part of the Department of Defense, the Secretary of Defense plays the leading role in the selection of the military officers to fill these two positions. This selection is coordinated with the DCI, but often only after the selection is made. However, both the NSA and the DIA conduct only intelligence-related activities. Because the DCI is accountable for the performance of these agencies, the DCI should also have a greater voice in selecting their directors. ${ }^{69}$

Finally, the analytical aspects of intelligence must play a part in any restructuring proposal. Over the next decade, intelligence analysis is likely to receive greater emphasis than in the past. ${ }^{70}$ In part, this reflects the increased availability of overt information from what were, until recently, closed societies. ${ }^{71}$ This emphasis will also result from having the first career intelligence analyst serve as DCI. As the Gates confirmation hearings made clear, however, there is a longstanding concern that intelligence analysis be objective and not

66. See text accompanying note 43 .

67. Exec. Order No. 12,036, supra note 10, § 1-602.

68. Exec. Order No. 12,333, supra note $11, \S 1.5(\mathrm{~m})$.

69. Cf., e.g., Turner, supra note 8, at 160 . Turner argues that the DCI, not the Secretary of Defense, should have the authority to "appoint and fire" the directors of the NSA and the "Satellite Reconnaissance Agency," a fictional name Turner gives to the agency that operates all intelligence satellites.

70. See, e.g., Colby, supra note 8, at 51-52 ("The major change in intelligence as a result of the new age of glasnost will be a final shift of the primary concentration of intelligence from collection to analysis. ... The new era will put [analysts] where they should be: at the center of the intelligence process.").

71. See, e.g., Turner, supra note 8 , at 161 . 
"politicized"- that intelligence analysis not be deliberately slanted to support the views of the policymakers.

The Intelligence Community structure itself can create the appearance that intelligence is being "politicized." For example, one of the reasons the Senate Armed Services Committee opposes having the Director of DIA report to the Assistant Secretary of Defense for Command, Control, Communications, and Intelligence is to avoid "the risk of politicizing DIA intelligence support by placing politically appointed officials in direct charge" of DIA operations and analysis. ${ }^{72}$ Similar considerations argue for a structure that continues the relative independence of the Intelligence Community from the control of policymaking officials. In his confirmation hearings, Dr. Gates identified eight principles that he intends to implement to ensure the objectivity of CIA intelligence analysis. ${ }^{73}$ Any restructuring should extend these principles, as applicable, to the other Intelligence Community agencies. Moreover, any restructuring should also preserve the Intelligence Community's longstanding tradition of filling most of its senior positions with career intelligence officers in order to enhance the objectivity of the analysis being provided to the President, other policymakers, and Congress.

\section{CONCLUSION}

The significant political changes taking place in the world require that restructuring the U.S. Intelligence Community receives proper consideration. At a minimum, this is necessary to ensure that the Intelligence Community serve the interests of U.S. policymakers as they confront these global changes. The President might, with some justification, assert that Intelligence Community structure primarily concerns the executive branch and should not be the subject of legislative concern. Congress, which has seen its role in intelligence policy increase in the last fifteen years, would certainly challenge that assertion.

Both the President and the Congress, however, must actively participate for Intelligence Community restructuring to be implemented and ultimately successful. They must agree on the targets and priorities to be addressed by the Intelligence Community. Once those issues are identified, the President should propose a workable structure with sufficient flexibility to adapt to the concerns

72. See S. REP. NO. 113, supra note 52, at 273.

73. The eight principles outlined by Gates were (1) stressing to all analysts the importance of integrity and objectivity of the product and accepting divergent views; (2) asking for the restoration of collegiality and civility that acknowledges that honest people can and will disagree; (3) including in the performance evaluation of all managers how well they encouraged the principles of openness to alternative views; (4) including the issue of integrity of analysis in every training course for analysts and managers; (5) encouraging the SSCI and HPSCI to reestablish analysis and production subcommittees that focus on oversight of the analytical process; (6) asking the President's Foreign Intelligence Advisory Board for its help and ideas; (7) considering the creation of an analysis council of retired former senior officials; and (8) soliciting ideas from analysts and managers on how to rebuild morale and ensure integrity and independence. Nomination Hearings, supra note 9, at 2906. 
of future Presidents and executive branch policymakers. Congress may then adopt or reject the President's proposal. If these steps are followed, the resulting Intelligence Community structure is more likely to be the most effective and efficient structure that our political system can produce. 


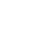

